\title{
SEX DIFFERENTIATION AND GROWTH PERFORMANCE TRIALS OF TWO GENOTYPES OF TILAPIA ADMINISTERED WITH ANDROGENIC HORMONE
}

\author{
Didik Ariyanto")\#, Komar Sumantadinata" ${ }^{*(*)}$, and Agus Oman Sudrajat ${ }^{* *)}$ \\ *) Research Institute for Fish Breeding and Aquaculture \\ *) Department of Aquaculture, Faculty of Fisheries and Marine Science \\ Jl. Agathis, Bogor Agricultural University, Darmaga Campus, Bogor 16680
}

(Received 10 June 2010; Accepted 9 November 2010)

\begin{abstract}
The aim of this study was to know the effect of dietary administration of androgenic hormone methyltestosterone on two sex genotypes of Nile tilapia i.e. XX and XY genotype, especially to sex ratio, growth rate, survival rate, food conversion ratio and harvest yield. XX genotype was obtained from XX male matted with XX normal female, and $X Y$ genotype was obtained from $Y Y$ super-male matted with $X X$ normal female. Methyltestosterone was administered seven days after larvae hatching for 28 days. After that, the fish were reared in hapas for 60 days and then placed in growout ponds for 120 days period. As check population, mixed sex genotype was used consisting of $50 \%$ XX genotype and $50 \%$ XY genotype. The result showed that dietary administration of methyltestosterone in XX genotype significantly increased male proportion about $82.42 \%$, compared with control XX population $(7.55 \%)$. The same treatment in genotype $X Y$ did not significantly increase the proportion of male (85.13\%), compared with control $X Y$ population (79.81\%). In grow-out ponds, all male population (XY genotype and sex reversed from XX genotype) have better growth rate than all female and mixed sex populations. Dietary administration of methyltestosterone in both of $X X$ and $X Y$ genotypes increased growth rate of these populations resulting in the increased of total biomass at harvest time.
\end{abstract}

KEYWORDS: Nile tilapia, androgenic hormone, sex ratio, growth rate and yield harvest

\section{INTRODUCTION}

Biologically, male of tilapia (Oreochromis niloticus) has a better growth than female (Popma \& Masser, 1999). Empirical data showed that all male population culture results a better production than mixed sex population. (Rakocy \& McGinty, 1989; Tave, 1996; Champan, 2000; Dunham, 2004; Gustiano, 2006). Due to sexual dimorphism, tilapia culture with mixed sex population has lower growth caused by early sexual maturity (Mair et al., 1995).

One of the most popular techniques to produce all or nearly all male population of tilapia is through sex reversal. Larvae of fish are treated with androgenic hormones especially methyltestosterone. Generally, sex reversal was conducted to the mixed genotype, $\mathrm{XX}-\mathrm{XY}$ which was obtained from normal matting. There

\# Corresponding author. Research Institute for Fish Breeding and Aquaculture. Jl. Raya 2 Sukamandi, Subang 41256, Indonesia. Tel.: + 62260520500

E-mail address: didik_ski@yahoo.com 
were reported studies that the use of androgenic hormone methyltestosterone successfully increased the male proportion, about 90-100\%. Due to the use of mixed genotype population, the effectiveness of this material for reversing fish sex of population remains unclear.

Besides that, almost all of the success research on fish sex reversal was stopped until the male-female proportion was determined. These results needed to be continued by evaluation of seed product in growing period so that the performance of theses seeds, especially in growing period can be traced.

The aim of this study was to know the effect of dietary oral administration of methyltestosterone on $X X$ and $X Y$ genotypes of Nile tilapia and to evaluate the performance of those populations in growing period in ponds such as growth rate, survival rate, size variability, food conversion ratio, and total biomass at harvest.

\section{MATERIALS AND METHODS}

The study was conducted at the Research Institute for Fish Breeding and Aquaculture Technology, Jl. Raya 2 Sukamandi, Subang, West Java in October 2008 - Mei 2009. This study was divided into 2 phases. The $1^{\text {st }}$ phase was sex reversal treatment using androgenic hormone, methyltestosterone and the $2^{\text {nd }}$ phase was rearing the fish which was obtained from $1^{\text {st }}$ phase in growing ponds. Factorial model with 2 factors, i.e. genotypes and treatments, was used as the research design. The genotypes used were $X X$ and $X Y$ genotypes, and the treatments applied were methyltestosterone and control. Mixed sex genotype was used as the check population. All treatments were done in 4 replicates.

\section{Material}

Material used in the $1^{\text {st }}$ phase was 3 genotypes of Nile tilapia larvae, i.e. $X X$ and $X Y$ genotypes and mixed sex genotype, $X X-X Y$. XX genotype was obtained from mating of $X X$ male with XX normal female. XY genotype was obtained from mating of YY super male (GESIT, Genetically Super male of Indonesian Tilapia) with $X X$ normal female. Both of $X X$ male and $Y Y$ super male were originated from the Institute of Aquaculture Development in Sukabumi, West Java. The XX normal female that was used as the brood stock was NIRWANA strain, that was originated from the Institute of Aquaculture Development in Wanayasa, West Java. The check population, mixed sex genotype $X X-X Y$, was obtained from normal mating (XY male with XX female) of NIRWANA strain.

\section{Experimental Method}

Both of male and female broodstocks were reared separately for 2 weeks before they were spawned in the ponds. Number of the broodstock spawned was 10 for male and 20 for female in each combination. Eggs were collected from the spawning ponds at 10 days after male and female brood stocks pooled. Incubating and hatching of eggs were conducted in hatching trays and completely hatched in 3-5 days. All larvae were reared in fiberglass batch in equivalent densities. After $5^{\text {th }}$ days after hatching, the larvae were stocked in 20 aquaria, with size of $60 \times 40 \times 40 \mathrm{~cm}$. The density of larvae was 5 fish/liter, or equivalent with 300 larvae in each aquarium.

Administration of methyltestosterone was done trough oral method. The dosage of methyltestosterone was $60 \mathrm{mg}$ which was diluted in $70 \%$ alcohol and then mixed with $1 \mathrm{~kg}$ of commercial feed (contain of $40 \%$ crude protein). The feed for both control and check populations was commercial feed similar to the commercial feed above. The larvae were fed 4-5 times a day starting from $7^{\text {th }}$ days after hatching for 28 days, at satiation. Both of siphoning and water exchange about $30-40 \%$ per aquarium were done every day. At the end of $28^{\text {th }}$ day, the fish were transferred to 20 hapas with size of $2 \times 2 \times 1 \mathrm{~m}$ installed in a $400 \mathrm{~m}^{2}$ earthen pond. Fish density was 250 fish in each hapa. The fishes were fed 3 times a day with commercial pellet feed (contain of $30-32 \%$ crude protein), at satiation, at 09.00 a.m., 01.00 p.m. and 05.00 p.m. The fish were reared in these hapas for 60 days. At the end of fingerling rearing time, identification of sex ratio, weighing, measuring of length and counting of all life fish from each hapa were conducted.

In the $2^{\text {nd }}$ phase, fish derived from $1^{\text {st }}$ phase as the material were used. In the $1^{\text {st }}-3^{\text {rd }}$ population (XY with $17 \alpha-\mathrm{mt}, \mathrm{XY}$ without treatment, $X X$ with $17 \alpha-m t)$, all males were selected individually, but in the $4^{\text {th }}$ population $(X X)$ all females were selected individually. In check population, $50 \%$ male and $50 \%$ female were selected individually. All fish were stocked and reared in 20 units of net cages installed in 5 
earthen ponds, size $400 \mathrm{~m}^{2}$. Each replication was placed in ponds randomly. But, all female and mixed sex populations were placed in separate ponds to avoid early sexual maturation. For 4 months, all fish were fed with commercial feed containing $28-30 \%$ crude protein. Feeding rates of $10 \%, 5 \%, 3 \%$, and $2 \%$ of their biomass, for $1^{\text {st }}, 2^{\text {nd }}, 3^{\text {rd }}$, and $4^{\text {th }}$ month, respectively were applied. Feed was given 3 times a day, at 09.00 a.m., 01.00 a.m., and 05.00 p.m.

\section{Data Analysis}

All data, i.e. average individual weight and length, survival rate, size variability, food conversion ratios and total biomass were collected from each treatment and replication. Individual weight and length were collected every 30 days while other data were collected at the end of the study. All data were analyzed with analysis of variance (ANOVA) and Duncan's multiple range test (DMRT) was used to identify differences among all populations.

\section{RESULTS AND DISCUSSION}

\section{Sex Differentiation}

At the end of the fingerling rearing period, average individual weight, survival rate and male proportion of each genotype and each treatment were recorded as shown in Table 1.

The effect of one material for sex reversal in organism can be evaluated trough several main parameters, such as sex ratio, growth rate, and survival rate. Nagy et al. (1981) stated that the success of one material for sex reversal in organism depends on several factors i.e. age of the organism, time and duration of treatment, and several environment factors. Hunter \& Donaldson (1983) also explained that the suc- cess of sex reversal by hormonal administration depends on gonad development interval time, especially when gonad was in labile period, so it was easy to be influenced by the material. According to Yamazaki (1983), sex reversal which was conducted in different species must be done in specific time and duration. This pattern was related to specific sex differentiation period in each species. Earlier administration time of the material than sex differentiation period in an organism might not be effective because the germinal cell did not respond to specific material, such as hormones and hormones analogue. The same phenomenon occurred when administration of the material was late. Piferrer et al. (1994) stated that hormonal administration which was done when labile period has gone, need higher dosage but may not be effective. Yamamoto (1969) explained that sex reversal will be successful if the treatment started in the early time of sex differentiation period.

Dietary administration of methyltestosterone increased the level of testosterone. High level of testosterone in body composition of fish could be directing sex differentiation to phenotypic male. Administration of methyltestosterone in XX genotype of Nile tilapia in this study resulted in $82.42 \%$ of phenotypic male. This result is in agreement with several earlier researches on the application of methyltestosterone for sex reversal in Nile tilapia. Gustiano (1992) showed that application of 15 $\mathrm{mg}$ methyltestosterone in $1 \mathrm{~kg}$ of feed increased the male proportion of Nile tilapia up to $79 \%$. Furthermore, Mantau (2001), Guerrero III \& Guerrero (2004) and Bowker et al. (2007) showed that application of the synthetic androgen at dosage of 15,50 , and 40 mg methyltestosterone in $1 \mathrm{~kg}$ of feed increased the

Table 1. Average individual weight (g), survival rate (\%) and male proportion (\%) of each population observed at the end of fingerling rearing time

\begin{tabular}{ccccc}
\hline Genotype & Treatment & $\begin{array}{c}\text { Survival rate } \\
\text { NO=250 }\end{array}$ & $\begin{array}{c}\text { Male proportion } \\
\text { N=NOXSR }\end{array}$ & $\begin{array}{c}\text { Weight } \\
\mathbf{N}=30\end{array}$ \\
\hline XY & $17 \alpha-\mathrm{mt}$ & $93.60 \pm 4.88^{\mathrm{a}}$ & $85.13 \pm 8.24^{\mathrm{a}}$ & $20.78 \pm 2.98^{\mathrm{a}}$ \\
& Control & $86.65 \pm 5.02^{\mathrm{a}}$ & $79.81 \pm 1.66^{\mathrm{a}}$ & $18.63 \pm 0.89^{\mathrm{a}}$ \\
$\mathrm{XX}$ & $17 \alpha-\mathrm{mt}$ & $94.20 \pm 3.27^{\mathrm{a}}$ & $82.42 \pm 2.29^{\mathrm{a}}$ & $18.23 \pm 1.56^{\mathrm{a}}$ \\
& Control & $93.60 \pm 2.17^{\mathrm{a}}$ & $7.55 \pm 2.83^{\mathrm{b}}$ & $18.69 \pm 2.74^{\mathrm{a}}$ \\
$\mathrm{XY}-\mathrm{XX}$ & -- & $92.40 \pm 3.12^{\mathrm{a}}$ & $56.56 \pm 2.30^{\mathrm{c}}$ & $14.74 \pm 1.71^{\mathrm{b}}$ \\
\hline
\end{tabular}

Expl. : The same superscripts in the same column showed no significant difference $(P>0.05)$ 
male proportion of Nile tilapia almost to $93 \%$, $96 \%$, and $95 \%$, respectively.

\section{Growth Performance}

At the end of the growing period in ponds, individually weight, survival rate, total biomass, and FCR of each genotype and each treatment were presented in Table 2 . In growing period, Nile tilapia which was administered with methyltestosterone has a better performance in growth than its control in each genotype. This phenomenon suggested that methyltestosterone is one of steroid hormone that encourages fish to releasing growth hormone (Higgs, et al., 1976). Hanson et al. (1983) found that sex reversed of Nile tilapia population has better growth than both of two male populations obtained from manual sexing and hybridization. Kuwaye et al. (1993) also found that $O$. mossambicus population which was treated with methyltestosterone had better growth than the untreated population. Yamazaki (1976) explained that methyltestosterone increased in both of digestive value and absorption rates of feed. Lone \& Matty (1981) also explained that administration of methyltestosterone will increase proteolitic enzyme activity in digestive system of mirror carps. XY genotype treated with methyltestosterone has average individual weight about $310.20 \mathrm{~g}$. It is equivalent with $16.40 \%$ better than that in XY control population and $77.68 \%$ better than that of mixed sex population. Sex reversed population with methyltestosterone in XX genotype has average individual weight about 248.09 g, equivalent with $23.59 \%$ better than that of control population and $42.10 \%$ better than that of mixed sex population. $X Y$ population has higher production than that of sex reversed $X X$ population. The results showed that using both of $X Y$ and sex reversed $X X$ populations resulted in higher production than that of all female and mixed sex populations. All female populations (XX genotype) had higher production than that of mixed sex population. Although not significantly different statistically, but total production of all female populations reached 15.06 $\mathrm{kg}$ in each pond. It means that its production was $17.47 \%$ better than that of mixed sex population which reached only $12.82 \mathrm{~kg}$ in each pond.

The pattern of growth of XX and XY genotypes of Nile tilapia which administered with methyltestosterone from 0 to 215 days were presented in Figure 1. In general, growth of mixed sex population was lower than that of all populations. Dietary administration of methyltestosterone significantly increased the growth rate of all genotypes in Nile tilapia. Until the end of fingerling rearing period for $3^{\text {rd }}$ month (95 days), all populations did not show the differentiation in individual average weight. In this period, average individual weight of all populations just reached $14-22 \mathrm{~g}$. Starting differences in individually body weight was shown at the end of $4^{\text {th }}$ month, especially for $X Y$ genotype. At this time, $X Y$ genotype reached individual body weight about $100 \mathrm{~g}$ but only $75-80 \mathrm{~g}$ for other genotypes. The differentiation of body weight will be more significant in the $7^{\text {th }}$ month, when the fish reached 215 days after hatching age. Due to the sexual dimorphism, different growth of all male and female populations compared with mixed sex population also was caused by reproductive behavior of these populations. Generally, Nile tilapia cultured in ponds will reach the maturity in 5-6 months, with 105-200 g of body weight (Popma \& Masser, 1999). Based on Indonesia National Standard No. 6138-2009, the gonad of Nile tilapia will mature when oocyte reached diameter of $\geq 2.5$ $\mathrm{mm}$. At the end of the $7^{\text {th }}$ month, several individual fish in mixed sex population have matured marked with the presence of females with some eggs in their mouth. Gonad maturity process needs more energy, so part of the energy which was obtained from feed was used for this process. According to Mair et al. (1995), early maturity in Nile tilapia inhibits the population growth due to sharing of energy for gonad maturation. Besides that, mouth breeding pattern of female of Nile tilapia broodstock results in less of feed consumption.

\section{Survival Rate and Total Biomass}

Survival rate of all populations of Nile tilapia in this study were relatively high, which was $86.65 \%-94.20 \%$ for fingerling and 84.06\%-94.06\% for later stage. According to several earlier studies, administration of methyltestosterone on fish and prawn did not affect the mortality rate of fish nor prawn. Kwon et al., (2000) reported that there was no statistical relationship between methyltestosterone treatments and mortality rate of fish. This result was supported by several studies in several species of fish and prawn such as by Piferrer et al. (1994) on salmon and Sarida (2005) on giant prawn. 


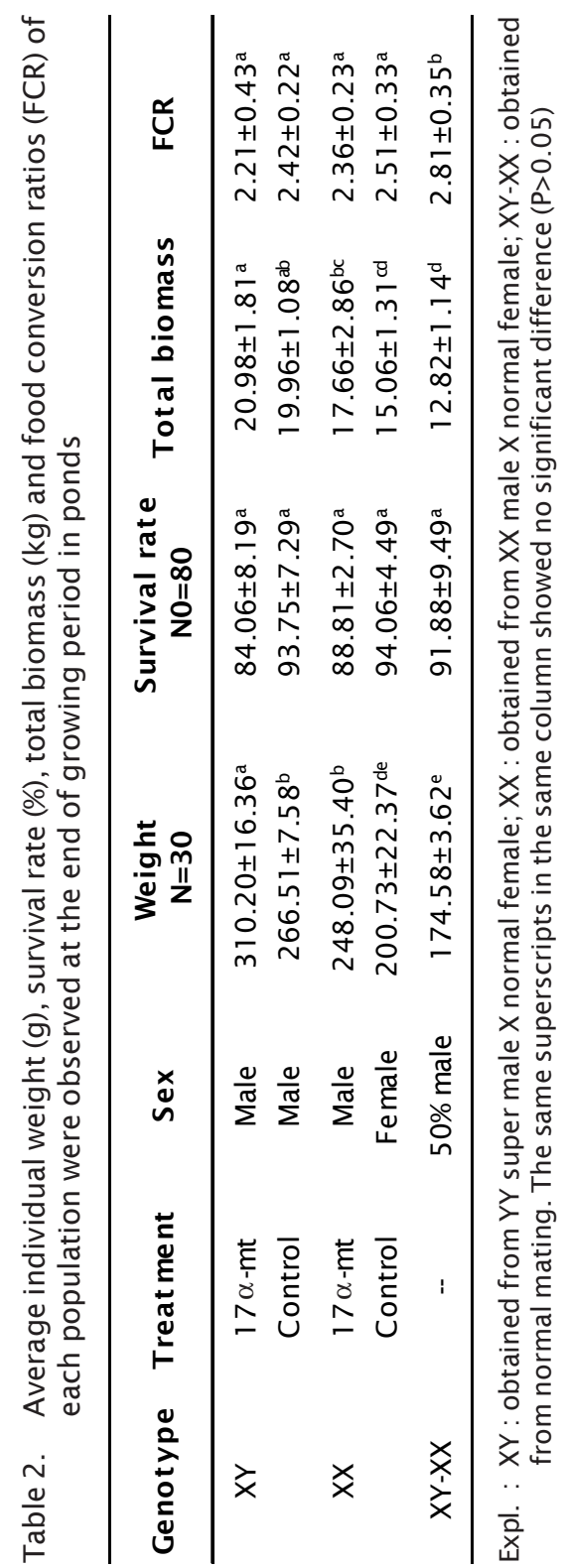




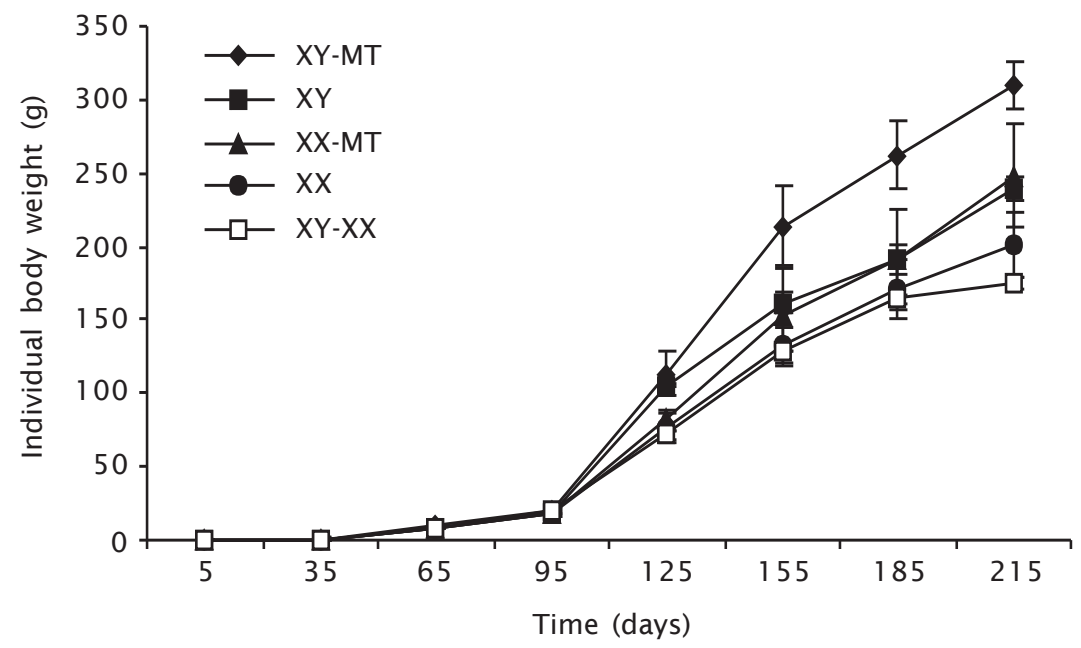

Figure 1. Growth of XX and XY genotype of Nile tilapia, treated with methyltestosterone. Mixed sex genotype XY-XX was used as the check population

In spite of survival rate of all populations were not significantly different, the total biomass among population were significantly different due to the difference of average of individually body weight at harvest time. Caused by mixed sex population, XY-XX has the lowest body weight. It affects not only total biomass at harvest time, but also to the food convertion ratio (FCR) of this population (Table 2). Both of total biomass and FCR of mixed sex population were the lowest than that of all populations. Although FCR's of treated and untreated of both of $X Y$ and $X X$ population were not significantly different, administration of androgenic hormone slightly increased the efficiency of feed which was indicated the low of FCR in these populations.

\section{CONCLUSION}

1. Androgenic hormone increased the male proportion in XX genotype but showed no effect on XY genotype of tilapia.

2. Androgenic hormone increased the growth rate, feed efficiency and total biomass at harvest time, both for $\mathrm{XX}$ and $\mathrm{XY}$ genotypes of tilapia.

\section{ACKNOWLEDGEMENT}

This study was funded by DIPA No. 186/ APBN/LRPTBPAT/2008 of the Research Institute for Fish Breeding and Aquaculture Tech- nology. We deeply thank to all technicians for their help during the research.

\section{REFERENCES}

Bowker, J., Bowman, M.P., Carti, D. \& Dotson, M. 2007. Histological determination of Tilapia gender following treatment with $17 \alpha$ methyltestosterone. Aquaculture America 2007. Therapeutic drug research session, February 2007. San Antonio TX. 21 pp.

Brodie, A. 1991. Aromatase and Its Inhibitors. An Overview. J. Steroid Biochem. Molec. Biol. 40: 225-261.

Chapman, F.A. 2000. Culture of Hybrid Tilapia: A Reference Profile. SIR. 1050. Univ. of Florida, 5 pp.

Dunham, R.A. 2004. Aquaculture and Fisheries Biotechnology: Genetic Approaches. CABI Publishing, $384 \mathrm{pp}$.

Guerrero III, R.D. \& Guerrero, L.A. 2004. Effects of androstenedione and methyl testosterone on Oreochromis niloticus fry treated for sex reversal in outdoor net enclosures. www.nraes.org/publications. Diunduh tanggal 22 Januari 2009.

Gustiano, R. 1992. Penggunaan hormon dalam pakan pada pembentukan ikan nila jantan. Warta Penelitian dan Pengembangan Pertanian, XIV(5):15-16.

Gustiano, R. 2006. Genetic improvement of Nile tilapia. Research Institute for Aquaculture, 
Bogor, $8 \mathrm{pp}$.

Hanson, T.R, Smitherman, R.O., Shelton, W.L. \& Dunham, R.A. 1983. Growth comparison of mono-sex tilapia produced by separation of sex, hybridization and sex reversal. P. 570- 579. In: Fishelson $\mathrm{L}$ and Yaron $\mathrm{Z}$. (Comp). Proceeding of the International symposium on tilapia in Aquaculture, Tel. Aviv. University, Israel, $624 \mathrm{pp}$.

Higgs, D.A., Donaldson, E.M., Dye, H. \& McBride, J.R. 1976. Influence of bovine growth hormone and $\mathrm{L}$ thyroxin on growth, muscle composition and histological structure of the gonads, thyroid, pancreas and pituitary of coho salmon (Oncorhynchus kisutch). J. Fish. Res. Board. Can., 33: 1,585-1,603.

Hunter, G.A. \& Donaldson, E.M. 1983. Hormonal sex control and its application to fish culture. In : Hoar WS and Randall DJ. (Eds). Fish Physiology. Vol. IXB. Academic Press. New York, p. 223-291.

Kuwaye, T.T., Okimito, D.K., Shimoda, S.K., Howerton, R.D., Hoa-Ren, L., Pang, P.K.T., \& Grau, E.G. 1993. Effect of 17-methyltestosterone on the growth of euryhaline tilapia, Oreochromis mossambicus, in fresh water and in seawater. Aquaculture, 113: 137-152.

Kwon, J.Y., Hashpanah, V., Hartudo, L.M., McAndrew, B. \& Penman, D. 2000. Masculinization of genetic female Nile Tilapia by dietary administration of an Aromatase inhibitor during sexual differentiation. J. of Exp. Zool., 287: 46-53.

Lone, K.P. \& Matty, A.J. 1981. The effect of feeding androgenic hormones on the proteolytic activity of the alimentary canal of carp (Cyprinus carpio). J. Fish. Biol., 18: 353358.

Mair, G.C., Abucay, J.S., Beardmore, J.A. \& Skibinski, D.O.F. 1995. Growth performance trials of genetically male tilapia (GMT) derived from YY-males in Oreochromis niloticus L. : On station comparisons with mixed sex and reversed male populations. J. Aqu., 137: 313-322.

Mantau, Z., Supit, A., Sudarty, Rawung, J.B.M., Buchari, U., Oroh, L., Sumampow, J., \& Mamentu, V. 2001. Penelitian adaptif pembenihan ikan mas dan maskulinisasi ikan nila di Sulawesi Utara. Laporan Hasil Penelitian. Instalasi Penelitian dan Pengkajian Teknologi Pertanian Kalasey, Sulawesi Utara, 12 pp.

Nagy, A., Beresenyi, M. \& Canyi, V. 1981. Sex reversal in Carp by oral administration of methyl testosterone. Can. J. Fish. Aquat. Sci., 38: 725-728.

Popma, T. \& Masser, M. 1999. Tilapia, Life History and Biology. SRAC Publication No. 283, $4 \mathrm{pp}$.

Piferrer, F., Zanuy, S., Carrillo, M., Solar, I.I., Devlin, R.H. \& Donaldson, E.M. 1994. Brief treatment with Aromatase Inhibitors during sex differentiation causes chromosomally female Salmon to develp as normal, functional male. J. of Exp. Zool., 270: 255-262.

Rakocy, J.E. \& McGinty, A.S. 1989. Pond Culture of Tilapia. SRAC Publ. No. 280, 4 pp.

Sarida, M. 2005. Effectivity of Aromatase Inhibitor and $17 \alpha$-methyltestosterone for Sex Reversal in Giant Prawn. Fisheries and Marine Science Fac. Bogor Agriculture University, $49 \mathrm{pp}$.

Tave, D. 1996. Selective breeding programmes for medium sized fish farms. FAO Fish. Tech. Paper 352, 122 pp.

Yamamoto, T. 1969. Sex differentiation. In: Hoar WS and Randall DJ. (Eds). Fish Physiology. Vol. III. Academic Press. New York, 1 17-157.

Yamazaki, F. 1976. Application of hormones in fish culture. J. Fish. Res. Board. Can., 33: 948-958.

Yamazaki, F. 1983. Sex control and manipulation in fish. J. Aqu., 33: 329-354. 